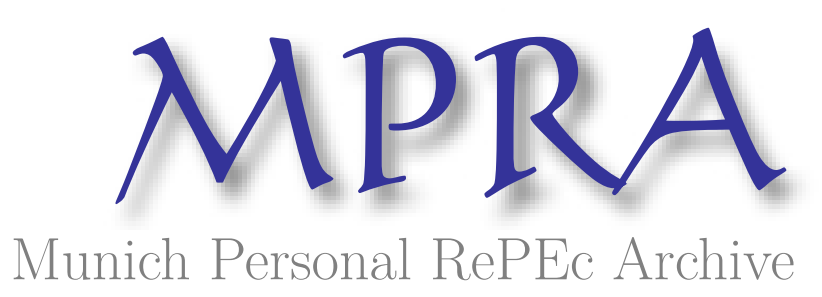

Economic Growth and Inequality in
Nigeria: Magnitudes and Challenges

AKPOILIH, Roland and FARAYIBI, Adesoji

University of Ibadan

9 May 2012

Online at https://mpra.ub.uni-muenchen.de/74156/

MPRA Paper No. 74156, posted 01 Oct 2016 15:44 UTC 


\title{
Economic Growth and Inequality in Nigeria: Magnitudes and Challenges
}

\author{
AKPOILIH Avura Roland \\ Department of Economics, University of Ibadan, \\ Ibadan, Oyo State, Nigeria \\ FARAYIBI Adesoji Oladapo ${ }^{1}$ \\ Centre for Allied Research and Economic Development, \\ Ibadan, Oyo State, Nigeria
}

\begin{abstract}
Economic growth is expected to lead to economic development and increase in the welfare of the masses. This is hoped to reduce the existing level of inequality. However, the most central problem in Nigeria economy today is that there is a sharp disconnect between the level of growth and development. What is rather obtainable is that there is growth without development because of the wide gap of inequality existing in the society. In this study we examine the phenomenon of growth-inequality nexus by employing trend analysis to examine the magnitude and the challenges of the prevailing inequality scenario in Nigeria. This paper therefore recommends good institutional framework and policy consistency to rectify the unwholesome situation of the high level of poverty and inequality prevailing in Nigeria.
\end{abstract}

\section{KEYWORDS: Economic Growth, Inequality, Poverty, Nigeria, Magnitude}

\section{Introduction}

The achievement of macroeconomic goals, namely full employment, stability of price level, high and sustainable economic growth and external balance, from immemorial, has been a policy priority of every economy, whether developed or developing. The realization of these goals undoubtedly is not automatic but requires policy guidance (Adefeso \& Bolaji, 2010). Economic growth and development is considered to be the necessary framework for realizing such objectives. It therefore implies that achieving a rapid, sustainable and pro-poor economic growth and development has often been stressed as a development policy objective of all countries of the

\footnotetext{
${ }^{1}$ Corresponding Author: E-mail: afarayibi2000@gmail.com
} 
world and African nations in particular. This seeming consensus reflects a new trend in development policy theorizing which sees inequality and by extension poverty as inimical to the achievement of the desired level of economic growth and development in all regions of the world.

Indeed, it is expected that economic growth should not only involve increase in the magnitude of national or aggregate outputs (GDP) alone, but also lead to increase in the welfare of the masses through poverty reduction and inequality in Nigeria. Thus achieving high level of social welfare invariably will imply reduction in inequality in all respect be it income, social and Gender inequality. However, it is regretted to note that Nigerian economy which is naturally endowed with immense wealth, still found a substantial portion of its population still in poverty which is characterized with high level of poverty. During the last three decades the country earned over US $\$ 300$ billion from crude oil alone. Today, this should have transformed into a huge socioeconomic development of the country. Instead, Nigeria's basic social indicators now place her as one of the 25 poorest countries in the world. (NBS, 2011). The Nigerian economy has recorded a rising growth in its GDP especially over the last decades. But this has not translated into accelerated employment and reduction in poverty among its citizens. This development has also been the case for most African countries. The endowment of crude oil can be seen as the major factor fueling the economic growth. The oil revenue should spread to the rest of the economy leading to a higher shared income for the owners of factors of production.

The objective of reducing the simultaneous problem of poverty and inequality among the poor economies of the world resulted into the framework of Millennium Development Goals (MDG) whose subsequent expansion in Nigeria led to the formation of National Economic Empowerment and Development Strategies (NEEDS). Yet, the objectives of these policies may not be achieved if the impediments to a rising domestic investment and employment creation are still evident in the socio-economic environment.

In fact the rising rate of income inequality in the Nigerian economy is usually one of the unpleasant results of economic growth without development. Hence, macroeconomic and development policy framework that could help in closing the wide inequality gap is desirable in this era. In this regard, Kuznets (1955) has it that inequality in the distribution of income increases up to a point and thereafter stabilizes before it starts declining in the course of an 
economy's growth, hence the emergence of the celebrated Kuznets inverted-U curve in economic growth literature.

There are also various studies that address the important issue of inequality in growth and development. For instance, Lagerlof (1999) examines the impact of gender inequality in education on fertility and economic growth. Using an overlapping generation framework, the paper argues that initial gender inequality in education can lead to a self- perpetuating equilibrium of continued gender inequality, with the consequences of high fertility and low economic growth. In the same vein, Schultz (1994) also argues that reducing gender inequality through access to education and the labour market will help reduce poverty, thereby increasing the rate of economic growth.

Therefore the basic questions which this paper intends to provide answers to include; what is the relationship between economic growth and inequality in Nigeria. What are the policy framework that could transform economic growth in Nigeria to economic development by reducing the level of inequality and poverty? Although there are studies that emphasized on growth-poverty nexus in Nigeria; Ogwumike, (2001), Obi, (2007) and Oyeranti and Ishola, (2012). In spite of these studies, there is still seemed to be dearth of literature that empirically estimates the magnitude of the current pace of growth-inequality nexus in Nigeria context. This is however underscored by lack of easily retrievable data. This study therefore seeks to contribute to the existing knowledge on the level of growth-inequality nexus in Nigeria by analyzing the trend in the trajectory of inequality and economic growth in Nigeria.

Following this introduction; section two deals with a review of relevance literature on inequality and economic growth in Nigeria. Section three handles the trend analysis of the pattern and trajectory of the movement of the magnitude of inequality in Nigeria and by extension poverty as well as other key macroeconomic variables and the challenging problems of such trends in inequality in Nigeria. Lastly, section four houses the summary, conclusion and recommendation.

\section{Literature Review}

\subsection{Economic Growth-Inequality: Theoretical Review}

The recent surge for understanding the level of connection or disconnect between economic growth and inequality in growth and development literature can be traceable to the seminal work 
of Kuznets (1955) which provides a background to describe the relationship between income inequality and economic growth. Kuznets posits that there exists a trade-off between growth and inequality, at least during early phases of economic modernisation. Describing this scenario, he maintains that as a country transforms from a subsistence-driven agricultural economy to a modernised one experiencing growth, it experiences increasing levels of income inequality, at some points, it get stables before it begins to decline again.

This initial theoretical conceptualization of growth-inequality nexus by Kuznets has been popularized by various authors and writers. But generally, a number of scholars, especially in the early 1990s submit that growth is indeed retarded by higher levels of income and land inequality. They arrived at this conclusion by adding measures of asset inequality and income/expenditure distribution to standard growth regressions. (notably Alesina \& Rodrik 1994; Pearson \& Tabellini 1994). Equally, Benabou (1996) in his detailed overview of the literature in the mid-1990s concludes: "These regressions, run over a variety of data sets and periods with many different measures of income distribution, deliver a consistent message: initial inequality is detrimental to long-run growth." Some subsequent cross-country regression studies have confirmed Benabou's conclusion, but it has also been challenged. Barro $(1991,2000)$ for example, finds no general relationship between inequality and growth. However, when he splits his sample into richer and poorer countries, he does find that growth is retarded by inequality in poorer countries, while in rich countries growth tends to be enhanced by inequality. Perroti (1996), on the other hand, concludes that the growth-retarding effects of inequality are less pronounced in poorer countries. Deininger and Squire (1998) find that growth is significantly depressed by income inequality (see also Rudra 2002) and in particular by high levels of initial land inequality in non-democratic economies.

Still on theoretical framework on economic growth-inequality nexus, we found that over the past five years, many economists have attempted to measure this relationship by adding inequality as an independent variable to some variant of Barro's cross-country growth regression. These studies generally find a negative and just-significant coefficient on inequality, leading most economists to conclude that inequality has a negative impact on growth. This line of research has received such widespread support that a recent survey of this work concludes: "These regressions run over a variety of data sets and periods with many different measures of income 
distribution, deliver a consistent message: initial inequality is detrimental to long-run growth" (Roland Benabou, 1996). This message has been so widely accepted that it has recently motivated a series of papers explaining the specific channels through which inequality might affect economic growth.

Although most of these papers focus on theories establishing a negative effect of inequality on growth, a careful reading of this literature suggests that this negative relationship is far less definitive than generally believed. In many models, the negative relationship depends on exogenous factors, such as aggregate wealth, political institutions, or the level of development. Many of these papers predict multiple equilibria, so that under certain initial conditions, inequality could have a positive relationship with economic growth. Moreover, several recent papers have developed models that predict a positive relationship between inequality and growth. For example, Gilles Saint-Paul and Thierry Verdier (1993) argue that in more unequal societies, the median voter will elect a higher rate of taxation to finance public education, which will increase aggregate human capital and economic growth. Benabou (1996a) develops a model based on heterogeneous individuals and shows that if the degree of complementarity between individuals' human capital is stronger in local than global interactions, then segregated and more unequal societies can experience higher rates of growth (at least in the short run). Oded Galor and Daniel Tsiddon (1997a, b) develop two theories of why inequality and growth could be positively related. In one model, a home environment externality helps determine an individual's level of human capital, and if this externality is strong enough, a high level of inequality may be necessary for growth to "take off" in a less-developed economy.

In a second model, Galor and Tsiddon argue that inequality increases during periods of major technological inventions, which, by enhancing mobility and the concentration of high-ability workers in technologically advanced sectors, will generate higher rates of technological progress and growth.

These theoretical papers predicting a positive relationship between inequality and growth have received less attention in this branch of literature because all recent empirical work has reported a negative relationship between these variables. Generally, income redistribution enhances effective reduction in inequality. 
To establish that, Figure 1 below demonstrates the nexus between economic growth and income redistribution.

\section{Figure 1: Theoretical linkages between Growth and Redistribution}

Theoretical Linkages between Growth and Redistribution

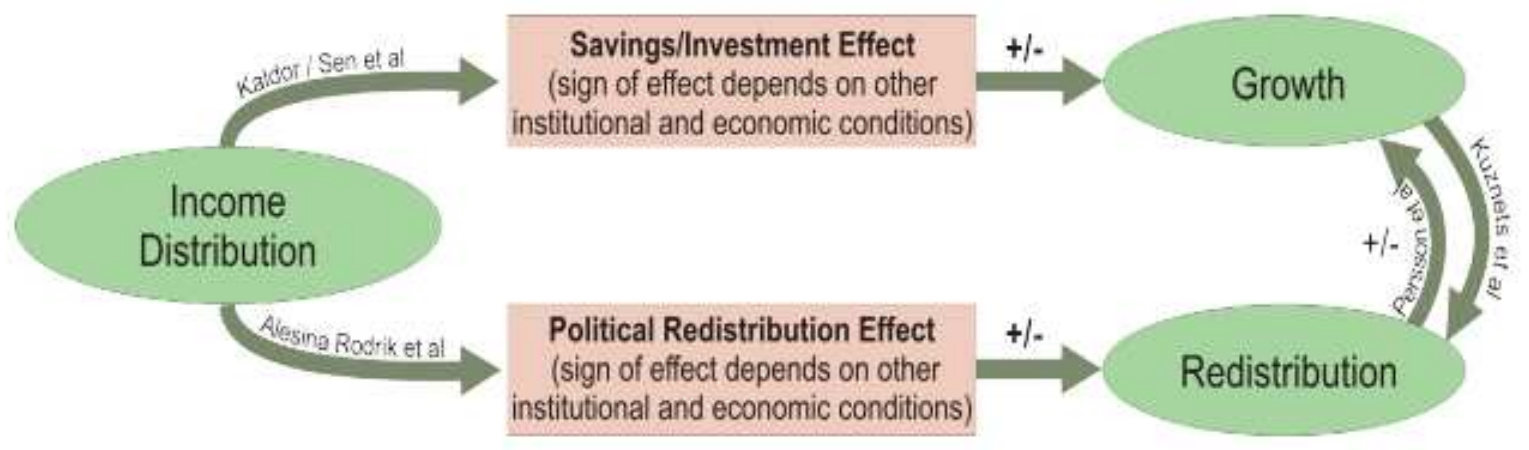

Source: Adapted from Khan (2009)

Khan (2009) in Figure 1 above theoretically summarizes the savings-investment link between distribution and growth. The link may take radically different signs depending on often implicit assumptions about initial conditions and the presence or absence of other necessary institutional and economic conditions. As profits are the incomes of capitalists, the higher investments that drive growth may be associated with a more unequal distribution of income. This implies that greater equality would have a negative effect on growth.

A second linkage between distribution and growth operates through the mechanism of political redistribution, shown by the arrow going through the lower box. Attempts by political organizations to achieve this redistribution, in turn, have a dampening effect on growth. The reason that inequality leads to low growth in these models is that political attempts to improve distribution in societies with initially poor distribution result in adverse effects for investment and growth because inequality would have a negative effect on growth by creating pressures for taxation and redistribution.

\subsection{Empirical and Methodological Review}

Using an improved data set on income inequality which not only reduces measurement error, but also allows estimation via a panel technique, Forbes (2000) was able to establish that panel estimation makes it possible to control for time-invariant country-specific effects, therefore eliminating potential sources of omitted-variable bias. His results suggest that in the short and medium term, an increase in a country's level of income inequality has a significant positive 
relationship with subsequent economic growth. This relationship is highly robust across samples, variable definitions, and model specifications. The link between factor income distribution and economic growth rests upon the proposition that capital accumulation drives economic growth and that the propensity to save out of wages is smaller than the propensity to save out of profits. Accordingly, the greater the proportion of income accruing to owners of capital the higher the rate of accumulation and economic growth (Compton Bourne, 2008).

The conclusion that Inequality is marginally bad for growth should not be taken to mean that high levels of Inequality are always bad for economic growth. However, high levels of Inequality are associated with lower growth rates. According to Nel (2003), there is no empirical evidence in the data of a Kuznets type trade-off between Economic growth and Inequality.

$\mathrm{Li}$ and Zou (1998) resolve empirically that income inequality is not harmful for growth. More recently, Forbes (2000) re-ran Perotti's investigation, using a high-quality data set not available to Perotti, and concludes that there is no evidence that indicates a strong negative effect of inequality on growth prospects, either in rich or in poorer countries. Banerjee and Duflo (2000) find that any change in the level of inequality, no matter in which direction or in which group of countries, affects subsequent growth negatively. Quah (2001) is of the opinion that "standard panel data methods produce results that are misleading, and when he corrects for this he finds that inequality is actually irrelevant for economic growth. Although these studies are not fully comparable, due to the fact that they use different data sets, regression equations and estimation techniques (see Banerjee \& Duflo 2000; Rodriguez 2000), it is at least obvious that the relationship between inequality and growth is as contentious today as it ever was."

In addition, Zhuang et al. (2010) identifies another mechanism through which inequality affects growth as a focus on institutions. They propose that there is a possible two-way causality between political institutions and inequality also between inequality and corruption. They observe that inequality could also affect growth through its negative impact on trust, cooperative norms, and social cohesion as these informal institutional mechanisms aid the reduction of transaction costs, encourage cooperation, and play a substitutive role when formal institutional arrangements are weak and ineffective. 


\section{Economic Growth and Inequality in Nigeria: Trends and Magnitudes 3.1 Trend in Nigerian Gross Domestic Product (GDP)}

The level of growth and development of the country hinges on the extent at which the national output increases. Usually, growth rate of gross domestic product have been used to measure the level of economic growth and development. Therefore, it is expected that the more the trend of growth in the real GDP, the higher the expected level of economic growth. It also implies that if such outputs are used judiciously, inequality will reduce and the social welfare function of the economy will be maximized. To vindicate the above magnitude in GDP growth, figures 1.1 below demonstrate that.

Table 3.1 Trend in Nigerian Real GDP and Saving

\begin{tabular}{lrr}
\hline \multicolumn{1}{l}{ PERIODS } & \multicolumn{1}{l}{ RGDP } & Saving \\
\hline $\mathbf{1 9 6 0 - 1 9 6 5}$ & 0 & 599.7 \\
$\mathbf{1 9 6 6 - 1 9 7 0}$ & 32070.4 & 1921.8 \\
$\mathbf{1 9 7 1 - 1 9 7 5}$ & 90080.4 & 6628 \\
$\mathbf{1 9 7 6 - 1 9 8 0}$ & 241455.4 & 24417.5 \\
$\mathbf{1 9 8 1 - 1 9 8 5}$ & 1216459 & 71568.3 \\
$\mathbf{1 9 8 6 - 1 9 9 0}$ & 2284876 & 163950.8 \\
$\mathbf{1 9 9 1 - 1 9 9 5}$ & 1635987 & 424504.9 \\
$\mathbf{1 9 9 6 - 2 0 0 0}$ & 3183507 & 1599580 \\
$\mathbf{2 0 0 1 - 2 0 0 5}$ & 5540745 & 5449934 \\
$\mathbf{2 0 0 6 - 2 0 1 0}$ & 8692851 & 19222993 \\
\hline
\end{tabular}

Source: CBN Statistical Bulletin, 2010 edition. 
Figure 3.1 GDP TREND FROM 1960-2010

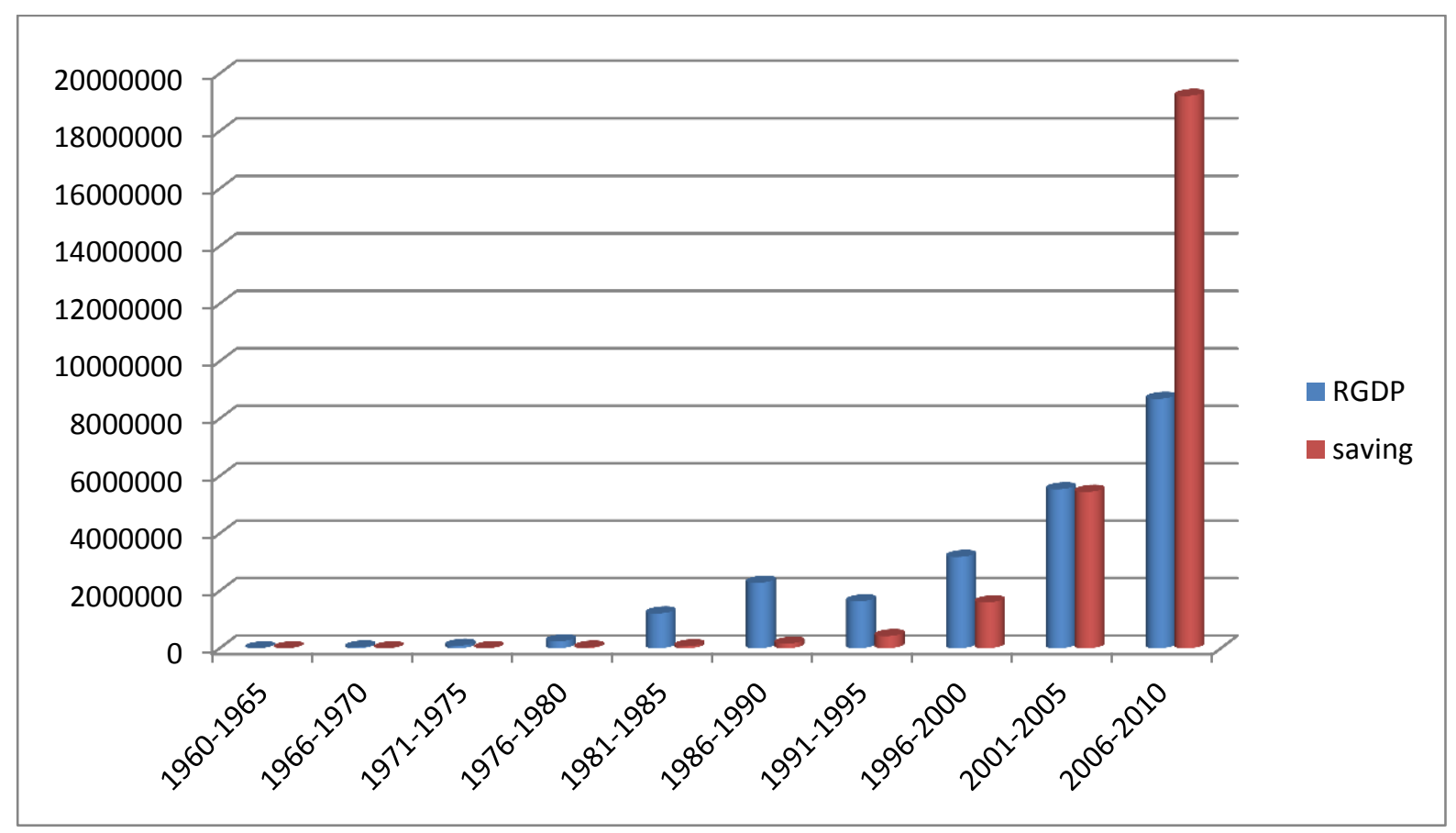

Source: Graphed by the Authors (2012).

It can be deduced from the graph above that the level of national savings in Nigeria for the five years interval as showcased in the graph above is not stable. That is the level of savings in the economy grew progressively from 1960 to 2010. It should be noted particularly that it is in the recent century, precisely $21^{\text {st }}$ century that the level of savings begin to flicker. Significantly, between 2006 and 2010, the rate of national savings is Nineteen billion, two hundred and twenty two million, and Nine hundred and Ninety three thousand $(19,222,993)$.

On the other hand, the level of growth in national real GDP, though followed similar trend with that of savings, but fluctuates more than the trend in national savings. From the graph, we can depict that Real GDP growth rate fluctuated from 1216459 to 1635987 between 1981-1985 and 1991-1995 respectively. Hence we can submit that increasing level of income inequalities in Nigeria may not be unconnected with such frequent fluctuations in Real GDP over the years.

\subsection{Trend in Aggregate Interest and inflation rates in Nigeria.}

Other macroeconomic variables that could influence growth and development in the country are the level at which price rises in the economy as well as the lending and saving interest rate. It is expected theoretically that inflation rate will have negative impact on economic growth and 
development in Nigeria. In this regard, the trend and magnitude of changes in this variable dictates the pattern at which economy grows. On the part of interest rate, the citizens, especially the low income earners and other local industrialist may not have the capacity to borrow from the banks at high interest rate and this will worsen the level of economic growth and development thereby leading to high level of inequality. Figure 2 below demonstrates the magnitudes and the trend in inflation rate and interest rate which will help in determining the levels at which the economy grows.

Table 3.2: Trends in Inflation and Interest Rate in Nigeria.

\begin{tabular}{lrrrrr}
\hline \multicolumn{1}{l}{ PERIOD } & INFLAT.RATE & DEPOSITRATE & \multicolumn{1}{l}{ PERIOD } & INFLAT.RATE & DEPOSITRATE \\
\hline $\mathbf{1 9 6 0 - 1 9 6 5}$ & 1.04 & 21.2 & $1986-1990$ & 30.25 & 174.45 \\
$\mathbf{1 9 6 6 - 1 9 7 0}$ & 2.13 & 39.4 & $1991-1995$ & 114.65 & 116.55 \\
$\mathbf{1 9 7 1 - 1 9 7 5}$ & 3.64 & 57.9 & $1996-2000$ & 422.84 & 170.68 \\
$\mathbf{1 9 7 6 - 1 9 8 0}$ & 7.13 & 78.65 & $2001-2005$ & 995.24 & 234.34 \\
$\mathbf{1 9 8 1 - 1 9 8 5}$ & 14.55 & 116.4 & $2006-2010$ & 2468.865 & 308.99
\end{tabular}

Source: CBN, Statistical Bulletin, 2010 edition.

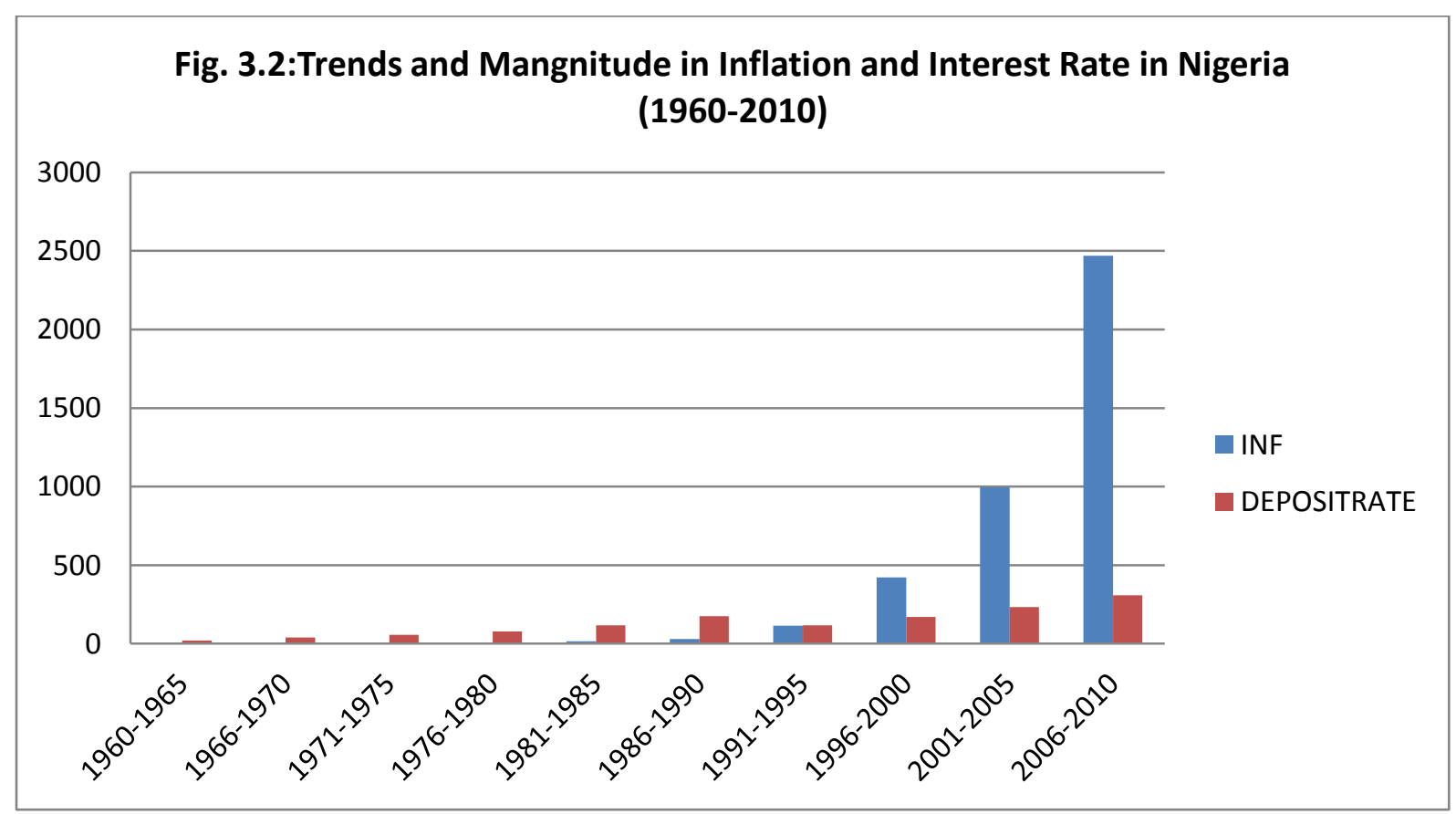

Source: Graphed by the Authors, 2012.

The central message obtained from the above trend in inflation and interest rate in Nigeria is that these variables are macroeconomic in nature which determines the level of economic growth and 
development. Hence, it can be found that inflation rate increased geometrically in the 20st century. It reaches the highest magnitude in 2010. The same trend is found with interest rate. It is noted to increase from the previous period gradually where it reaches it highest peak in 2010 .

\subsection{Trend and Composition of Consumption in Nigeria}

One striking feature that calls for attention is the persistent declining trend in private consumption since 1981. Data from CBN, (2010) indicates that private consumption constitutes about $68.2 \%$ of the Nigerian aggregate expenditure, yet it has remained unimpressive, declining from $-5.7 \%$ in 1981 to about $-36.6 \%$ in 2010. See Table 3 and figure 3 below for detail.

Table 3.3: Private, Government and Total consumption expenditure, import and real exchange rate data for Nigeria from 1981 to 2010

\begin{tabular}{lllllll}
\hline YEARS & $\begin{array}{l}\text { Private Consumption } \\
\text { (N Million) }\end{array}$ & $\begin{array}{l}\text { Government } \\
\text { Consumption } \\
\text { Million) }\end{array}$ & $\begin{array}{l}\text { Total Consumption } \\
(\mathbf{N}\end{array}$ & $\begin{array}{l}\text { Import } \\
\text { (N Million) } \\
\text { (N'million) }\end{array}$ & $\begin{array}{l}\text { Real } \\
\text { Rate (N/US\$) }\end{array}$ & $\begin{array}{l}\text { Exchange } \\
\text { (N) }\end{array}$ \\
\hline $\mathbf{1 9 8 1 - 1 9 8 5}$ & 193768.15 & 12233.45 & 260308.9 & 9180.72 & 23.48 \\
\hline $\mathbf{1 9 8 6 - 1 9 9 0}$ & 168772.87 & 13437.98 & 230414.56 & 13511.46 & 103.92 \\
\hline $\mathbf{1 9 9 1 - 1 9 9 5}$ & 210328.23 & 14786.51 & 229622.29 & 209908.02 & 118.66 \\
\hline $\mathbf{1 9 9 6 - 2 0 0 0}$ & 189574.37 & 16055.05 & 318927.33 & 631177.02 & 85.21 \\
\hline $\mathbf{2 0 0 1 - 2 0 0 5}$ & 1942471.85 & 207215.72 & 2227011.88 & 7625863 & 624.44 \\
\hline $\mathbf{2 0 0 6 - 2 0 1 0}$ & 1438542.81 & 1046543.01 & 3046700.54 & 19315420 & 430.34
\end{tabular}

Source: CBN, Statistical Bulletin, 2010 edition.

Fig.3.3: Trend and Magnitude in Consumption, and Import in Nigeria (1960-2010)

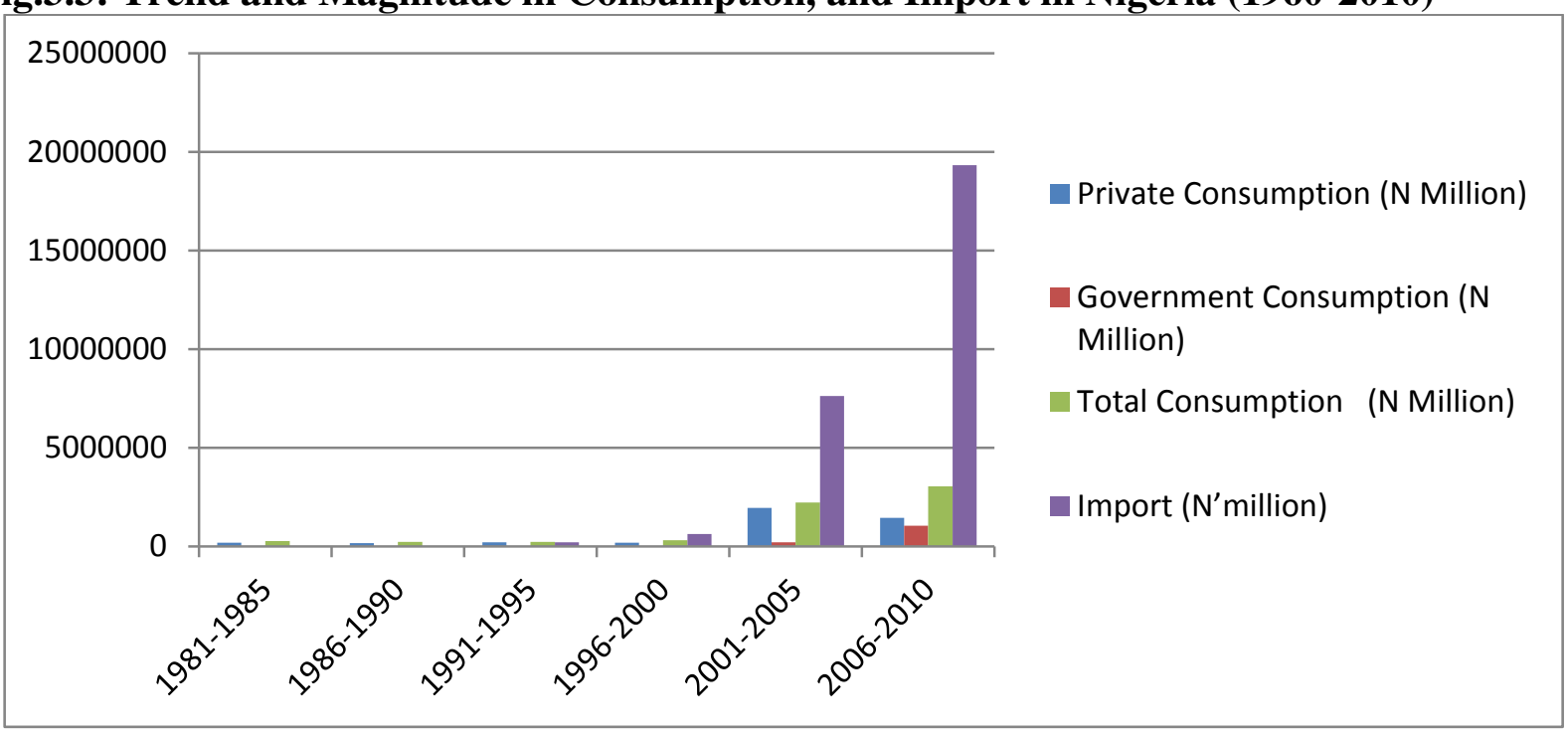

Source: Graphed by the Authors, 2012. 
As obtained above, in the table and in the trend of consumption, consumption fell during the period before SAP era from $\$ 193,768.15$ to $\$ 168,772.87$ in $1986-1990$ is due to the introduction of SAP. Consumption increased from $\$ 168772.87$ to $\$ 210,328.23$ in 1991-1995 due to heavy dependence on imported goods. There was also an increase from $\$ 210,328.23$ to $\$ 249,965.32$ in1996-2000. There was a sharp decline from $\$ 1942471.85$ to $\$ 1438542.81$ in 2001 to 2005 and 2006-2010 respectively. This rise and fall in the magnitude of private consumption due to increase in external reserves generated from the oil and gas sector and telecommunication sector.

\subsection{Inequality Trend in Nigeria.}

The Nigerian economy is basically characterized by large population of rural dwellers whose major occupation is agriculture and a smaller urban capital intensive sector, which has benefited most from the exploitation of the country's resources and from the provision of services that successive governments have provided. This existence of this economic duality or the real sector duality which differentiated the urban areas from the rural areas in Nigeria has also contributed to the persistence of different level of social inequality in Nigeria. A fundamental problem with Nigeria's past pattern of development has been that the incentive regimes that prevailed for most of the last two decades have tended to favour the urban modern sector. Nevertheless, the poor in Nigeria are not a homogeneous group. They can be found among the six geo-political zones in Nigeria. For instance table 2.1 and figure 2.1 below shows the distribution of inequality and poverty in Nigeria base on Human Development Index by NBS, 2010.

Table 3.4: Nigeria's Human Development Summary Statistics by Zones

\begin{tabular}{|l|l|l|l|l|l|}
\hline Zones & $\begin{array}{l}\text { Human } \\
\text { Poverty } \\
\text { Index } \\
\text { (HPI) }\end{array}$ & $\begin{array}{l}\text { Gender } \\
\text { Empowerment } \\
\text { Measure } \\
\text { (GEM) }\end{array}$ & $\begin{array}{l}\text { Human } \\
\text { Development } \\
\text { Index } \\
\text { (HDI Value) }\end{array}$ & $\begin{array}{l}\text { Gender } \\
\text { Development } \\
\text { Measure } \\
\text { (GDM) }\end{array}$ & $\begin{array}{l}\text { Inequality } \\
\text { Measure } \\
\text { (INQ) }\end{array}$ \\
\hline North Central & 34.65 & 0.244 & 0.490 & 0.478 & 0.49 \\
\hline North West & 44.15 & 0.117 & 0.420 & 0.376 & 0.44 \\
\hline North East & 48.90 & 0.118 & 0.332 & 0.507 & 0.42 \\
\hline South west & 21.50 & 0.285 & 0.523 & 0.455 & 0.38 \\
\hline South East & 26.07 & 0.315 & 0.471 & 0.575 & 0.41 \\
\hline South-South & 26.61 & 0.251 & 0.573 & & 0.48 \\
\hline
\end{tabular}

Source: NBS \& NHDR Team survey, 2009-2010 
Figure 3.4: Nigeria's Human Development Summary Statistics by Zones

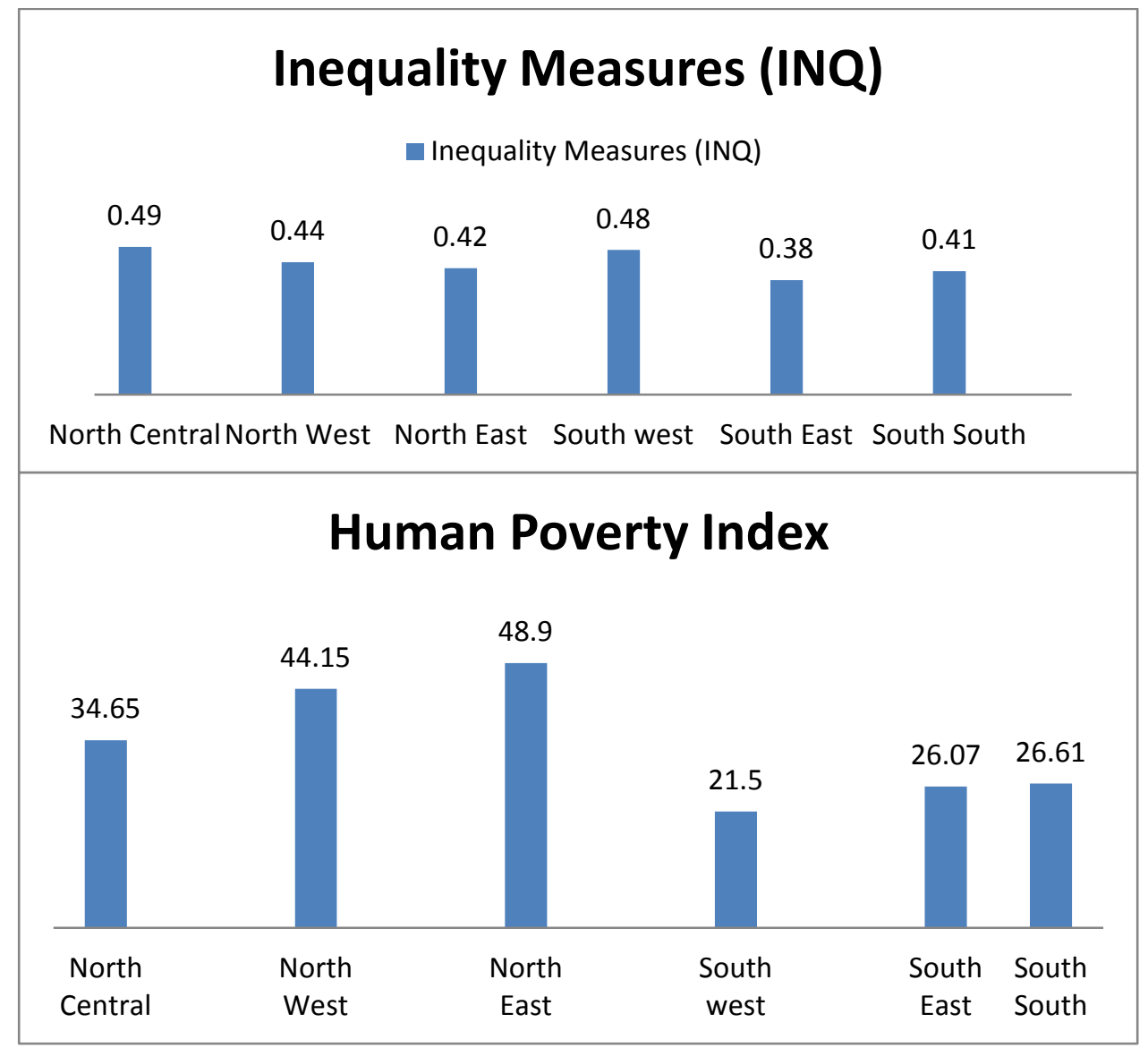

Source: Graphed by the Authors with data from NBD and NHDR

The above graphs show the level of inequality and poverty across the six geo-political divisions in Nigeria. It can be deduced from the graph that North- Eastern zone had the highest poverty index in the country of about 49 percent. This trend is followed by North western zone with 44.12 percent, North central $34.65 \%$ ), south-south (26.61\%), south-east (26.07\%) and south-west with $21.5 \%$. On the other hand, south west which hitherto had the lowest level of poverty index exhibits high level of inequality (0.48). This is followed by north central $(0.49 \%)$, North West (0.44), north east $(0.42 \%)$, south-south $(0.41 \%)$ and south-east $(0.38 \%)$. It can be deduced from the above graphs that the level of poverty and inequality in Nigeria varies across the six geopolitical zones in Nigeria.

Poverty in Nigeria is partly a feature of high inequality which manifests in highly unequal income distribution, differing access to basic infrastructure, education, training and job opportunities. High inequality could undermine the country's prospects of achieving the MDGs. 
It is often said that the true barometer for measuring the impact on poverty is the Gini coefficient index of inequality. Many recent studies and statistics have shown that poverty is evidenced in inequality. And in Nigerian situation, inequality basically indicates high levels of institutional failures in the provision of equal opportunities for all to have access to education and other social infrastructural facilities. We submit from the above that inequality-growth nexus is apparent in Nigeria which has been responsible for low level of economic growth and development.

\section{Conclusion and Policy Implications}

This paper used trend analysis to examine the magnitude of inequality as an inhibitor to high level of economic growth and development in Nigeria. Inequality decreases growth through decreased investment and government inefficiency decreases growth through corruption by decreasing the productivity of existing resources and in-directly through reduced investment. The results of our trend analysis so far suggested that increasing the well-being of the majority of citizens in Nigeria can be greatly enhanced by reducing the prevailing level of inequality in Nigeria. This can be done if the government who largely control the resources of the state should rise to their responsibility. It is suggested here that strong institution of the state, strong legal framework and institution can address the level of resource mismanagement and rather affect people's lives. It is also recommended here that interagency action of the state and the private stakeholders of the economy could contributes their quota in helping and reversing the inequality coefficients in Nigeria. 


\section{References}

Adefeso, H.A. and Mobolaji, H.I. (2010). The fiscal - monetary policy and economic growth in Nigeria: Further empirical evidence. Pakistan Journal of Social Sciences, 7 (2), 137-142.

Banerjee, A. and Duflo, E. (2003). Inequality and Growth: What Can the Data Say? Journal of Economic Growth. 8(1), 267-99

Barro, R. (1991). Economic Growth in a Cross-section of Countries. Quarterly Journal of Economics. 106 (2), 407-43.

Barro, R. (2000). Inequality and Growth in a Panel of Countries. Journal of Economic Growth. $5(1), 5-32$.

Benabou, R. (1996). Inequality and Growth, in Ben S. Bernanke and Julio J. Rotemberg, eds., NBER macroeconomics annual 1996 .Cambridge, MA: MIT Press, 11-74.

Compton Bourne, O.E. (2008). Economic Growth, Poverty and Income Inequality. Sir Arthur Lewis Memorial Conference, University of the West Indies St. Augustine Campus Trinidad and Tobago.

Central Bank of Nigeria (2010) Statistical Bulletin, CBN, Abuja

Deininger, K. and Squire, L. (1998). New Ways of Looking at Old Issues: Inequality and Growth. Journal of Development Economics. 57(2), 259 - 87.

Forbes, K.J. (2000). A Reassessment of the Relationship between Inequality and Growth. The American Economic Review. 90 (4), 120-34. 
Galor, Oded and Tsiddon, Daniel. (1997). The Distribution of Human Capital and Economic Growth." Journal of Economic Growth, 2(1), 93-124

Galor, Oded and Tsiddon, Daniel. (1997). Technological Progress, Mobility, and Economic Growth. American Economic Review, 87(3), pp. 363-82.

Gyimah-Brempong, K. (2002). Corruption, economic growth, and income inequality in Africa. Economics of Governance. Vol.3 .Springer-Verlag.

Khan, M.H. (2009). Governance, Growth and Poverty Reduction. DESA Working Paper No. 75. ST/ESA/2009/DWP/75.

Korzeniewicz, R.P \& Moran, T.P. (2005). Theorizing the Relationship between Inequality and Economic Growth. Theory and Society Springer. 34(3), 22-34.

Kuznet, S. (1955). Economic Growth and Income Inequality. The American Economic Review, 45(1), 1-28.

Lagerlof, N. (1999), Gender Inequality, Fertility, and Economic Growth. Mimeograph. Department of Economics, University of Sydney.

Li, H. and Zou, H. (1998). Income Inequality is Not Harmful for Growth: Theory and Evidence. Review of Development Economics. 2(3), 318-334. 
Nigerian Bureau of Statistics, (2010). Nigerian Poverty Profile. Available at www.nbs.ng.

Nel, P. (2003). Income Inequality, Economic Growth And Political Instability in Sub-Saharan Africa. Journal of Modern African Studies. 41(4), 61 1-639.

Panizza, U. (2002). Income Inequality and Economic Growth: Evidence from American Data. Kluwer Academic Publishers Journal of Economic Growth, 7(1), 223-35.

Perotti, R. (1996). Growth, Income Distribution and Democracy. Journal of Economic Growth. 1(2), 149-87.

Persson, T. and Tabellini, G. (1994). Is Inequality Harmful for Growth? American Economic Review. 84(3), $600-21$.

Quah, D. (2001). Some Simple Arithmetic On How Income Inequality And Economic Growth Matters. Unpublished paper, Economics Department, London School of Economics. Available at www.econ.lse.ac.uk/-dquah.

Rodriguez, F. (2000). Inequality, Economic Growth and Economic Performance. Background Note for the 2000 World Development Report, available from www.econ.umd.edu/rodriq-f.

Rudra, N. (2002). Openness, Welfare Spending, and Inequality in the Developing World. Paper delivered at Conference on 'Globalisation, Growth and Inequality', Centre for the Study of Globalisation and Regionalisation, Warwick University. 
Schultz, T.W. (1961) Investment in Human Capital. American Economic Review: March pp 117.

UNDP (2009).SUMMARY: Human Development Report Nigeria. 2008 - 2009; Achieving growth with equity. United Nations Development Programme. Abuja.

Verbeek, Marno and Nijman,( 1996) Theo. "Incomplete Panels and Selection Bias," in La'szlo' Ma'tya's and Patrick Sevestre, eds., The econometrics of panel data. Dordrecht: Kluwer Academic, pp. 449-90.

Zhuang et al. (2010) Governance and Institutional Quality and the Links with leconomic Growth and Income Inequality: With Special Reference to Developing Asia. ADB Economics Working Paper Series No. 193. Asian Development Bank, Philippines. 